\title{
Influence of Early In Utero Infection with Human Cytomegalovirus on the Course of Pregnancy
}

\author{
Christine Wenig ${ }^{1,}$, Brigitte Schlehofer ${ }^{2}$, Gernot K. Beisler ${ }^{3}$, Paul Schnitzler ${ }^{4}$ and \\ Jörg R. Schlehofer ${ }^{*}, 1$
}

\author{
${ }^{I}$ Deutsches Krebsforschungszentrum, Tumorvirologie, F010, Im Neuenheimer Feld 242, D-69120 Heidelberg, Germany \\ ${ }^{2}$ Deutsches Krebsforschungszentrum, AG Umweltepidemiologie C030, Im Neuenheimer Feld 280, D-69120 Heidelberg, \\ Germany \\ ${ }^{3}$ Ärztehaus, Wildbader Str. 31, 75323 Bad Wildbad-Calmbach, Germany \\ ${ }^{4}$ Hygiene Institut, Abteilung Virologie, Im Neuenheimer Feld 324, Universität Heidelberg, D-69120 Heidelberg, \\ Germany \\ ${ }^{\S}$ Present address: Neurologische Abteilung, Asklepios Klinik Wandsbek, Alphonsstr. 14, D-22043 Hamburg
}

\begin{abstract}
Previous studies of in utero-infection with the human cytomegalovirus (HCMV) were focused on HCMVseropositive women. Here, we assessed the clinical relevance of HCMV infection in normal pregnancies. In a prospective cohort study, amniotic fluids from 403 pregnant women undergoing amniocentesis for non-virological reasons were tested for HCMV DNA (nested PCR analysis of amniotic fluids), and sera of mothers and their neonates for IgG and $\operatorname{IgM}$ antibodies against HCMV (ELISA). Clinical data were obtained through questionnaires at the time of amniocentesis and at delivery. HCMV DNA was found in 3\% of amniotic fluids, and was associated with an increased occurrence of preterm delivery, reduced birth weight, premature labor and preeclampsia. The seroprevalence of HCMV-specific IgG in maternal and newborn sera was about $40 \%$, IgM was very rarely found in mothers, and in none of the neonates. Serological results were not associated with pregnancy complications. Hence, in utero HCMV infection is rare in normal pregnancies but might have consequences for the course of pregnancy.
\end{abstract}

Keywords: Cytomegalovirus, serology, in utero infection, pregnancy, amniocentesis, preeclampsia, preterm delivery.

\section{INTRODUCTION}

Human cytomegalovirus (HCMV) infection is the most frequent congenital virus infection and a leading cause of neonatal morbidity with approximately $1 \%$ of all neonates being infected [1-4]. At birth about $10 \%$ of infected newborns have been reported to be symptomatic with multiorgan involvement [5]. Another $10 \%$ of the initially asymptomatic newborn infants develop clinical manifestations usually during the first two years of life. Among these long term pathologies, mental retardation and sensorineural hearing loss are commonly found [6]. In utero infection with HCMV results either from primary or recurrent maternal infection [4, $7,8]$. In Europe, $55-60 \%$ of women of childbearing age are seronegative for HCMV antibodies and thus susceptible for primary HCMV infection during pregnancy. Compared to recurrent infection (either due to reactivation of endogenous virus or reinfection with different HCMV strains) it is assumed that primary maternal infection poses a greater risk for congenital disease. This is because transmission to the fetus is more likely (transmission rates about $40 \%$ in seronegative women versus $0.5-1.2 \%$ in seropositive mothers), and

*Address correspondence to this author at the Deutsches Krebsforschungszentrum, Tumorvirologie, F010, Im Neuenheimer Feld 242, D-69120 Heidelberg, Germany; Tel: +49 62214249 75; Fax: +49 62214249 62;

E-mail: j.schlehofer@dkfz.de clinical symptoms are more severe [9]. Therefore the differentiation between primary and recurrent maternal HCMV infection may be important for the management of pregnancy [10]. Recently, it has been reported that symptomatic congenital HCMV infection following recurrent maternal infection seems to be more frequent than previously recognized $[11,12]$. With the exception of the study of Baschat $e t$ al. [13], in reports dealing with the clinical outcome of congenital HCMV infection, the study population was chosen in advance based on serological status or ultrasonographic findings indicating HCMV infection. In contrast, in this study we have analyzed the clinical relevance of HCMV serology and HCMV in utero infection in a prospective cohort of 403 pregnant women not selected for infection with this virus.

\section{MATERIAL AND METHODS}

\section{Study Design and Characteristics of the Study Popula-} tion

In collaboration with seven obstetrical hospitals we performed a prospective cohort study in order to determine the prevalence and clinical relevance of HCMV infection in women undergoing amniocentesis. Between February 1999 and April 2000 we studied a total of 403 pregnant women who had amniocentesis for various non-virological reasons, e.g. genetic issues (cf., Table 1, in a specialized gynecologic practice of the area of the city of Pforzheim (about 150.000 inhabitants, Southwest Germany). After explanation of the 
aim and consequences of the investigation, all women undergoing amniocentesis during this time period (see above) participated in the study, with written informed consent. Prior to starting, the study was approved by the State's Ethics Committee.

Table 1. Indication for Amniocentesis

\begin{tabular}{|l|c|c|}
\hline \multicolumn{1}{|c|}{ Indication } & n & \% \\
\hline \hline Age* $^{\prime}$ & 321 & 79.7 \\
\hline Psychological reasons & 37 & 9.2 \\
\hline $\begin{array}{l}\text { Suspected chromosomal aberrations including } \\
\text { pathological Triple test }\end{array}$ & 17 & 4.2 \\
\hline Morphological abnormalities & 8 & 2.0 \\
\hline Various medical conditions** & 18 & 4.9 \\
\hline Total & $\mathbf{4 0 3}$ & $\mathbf{1 0 0}$ \\
\hline
\end{tabular}

* In Germany, in pregnancy care management (covered by the Health Insurances), a women of 34 years or older is recommended for amniocentesis because of the statistically increasing age-dependent risk of trisomy. In 33 cases, women aged between 31 and 34 years asked for genetic analysis because of their (relatively high) age.

** e.g., chromosomal aberrations in the family history or in previous pregnancies; morphological abnormalities in sisters and brothers; specific comorbidities

In pregnancy care management, covered by the German health insurances, a women of 34 years or older is recommended to have amniocentesis because of the statistically increasing age-dependent risk of trisomy. Therefore, in the vast majority of cases $(n=321)$ the indication of amniocentesis was the age of the mother. In other cases, the reasons were psychological $(n=37)$, suspected or familial chromosomal aberrations $(n=12)$, a pathologic Triple test $(n=5)$, morphological abnormalities suspected by ultrasound $(n=8)$, or other medical indications $(\mathrm{n}=20)$ (cf., Table 1).

The participants of the study $(n=403)$ had a median age of 35 years with an age range from 18 to 43 years.

The amniotic fluid samples that were available for analysis had been taken between the $14^{\text {th }}$ and $19^{\text {th }}$ week of pregnancy, despite knowing that this was not the optimal time point for HCMV analysis. Two amniotic fluid aspirates are obtained: the first one, which may also contain maternal material, is usually discarded. The second one, which contains solely fetal material, is used for further diagnostic tests. In the present study, 382 "first" and 403 "second" aspirates could be tested for HCMV DNA (Scheme 1).

In addition, at the time of amniocentesis and at the time of delivery, maternal blood samples were withdrawn of which 387 and 256, respectively, could be analyzed. Twenty-seven women were lost to follow-up (i.e. no information at the time of delivery), and for 109 women and 123 newborns serum samples were not sent by the hospital (cf., Scheme 1). We obtained serum samples (cord blood) from 253 neonates of which 245 were testable, i.e., $65 \%$ of those 376 pregnancies that could be followed up until delivery (cf., Scheme 1).

Furthermore, two detailed questionnaires were developed and filled in by the doctors (at amniocentesis and delivery), to get information about maternal diseases possibly influencing pregnancy (e.g. diabetes mellitus), about previous pregnancies, abortions or miscarriages, and about the course of the current pregnancy such as duration of pregnancy (preterm delivery: duration $\leq 259$ days post menstruationem, post-date delivery: $\geq 294$ days p.m.), delivery conditions, and the immediate postnatal condition of the newborn. For 403 women, the first questionnaire (time of amniocentesis) was sent back (response rate 100\%), and for 376 women the second questionnaire was also returned (filled in at delivery; response rate $93.3 \%$; cf., Scheme 1).

The number of previous pregnancies of the participants varied between none ( $\mathrm{n}=85$ women) and 12 , including miscarriages and stillbirths at various frequencies. There were more previous miscarriages in women with a higher number of previous pregnancies (cf., Table 2).

In order to identify possible (non-viral) risk factors for the course of pregnancies and child development we collected data on nicotine and alcohol consumption. $73.2 \%$ of the women reported to be non-smokers, $10.7 \%$ occasional smokers, and $15.9 \%$ to smoke regularly; for one woman, data were missing. Drinking alcohol was denied by $82.6 \%$ of the study participants, $16.6 \%$ of the women consumed alcohol sporadically; two women reported regular drinking of alcohol, and two women gave no information. At the time of amniocentesis, the following medical risk factors for pregnancy complications were reported: gestational hypertension $(5 \%)$, bleeding $(12.4 \%)$, gestational diabetes $(1.7 \%)$

Study design and materials tested

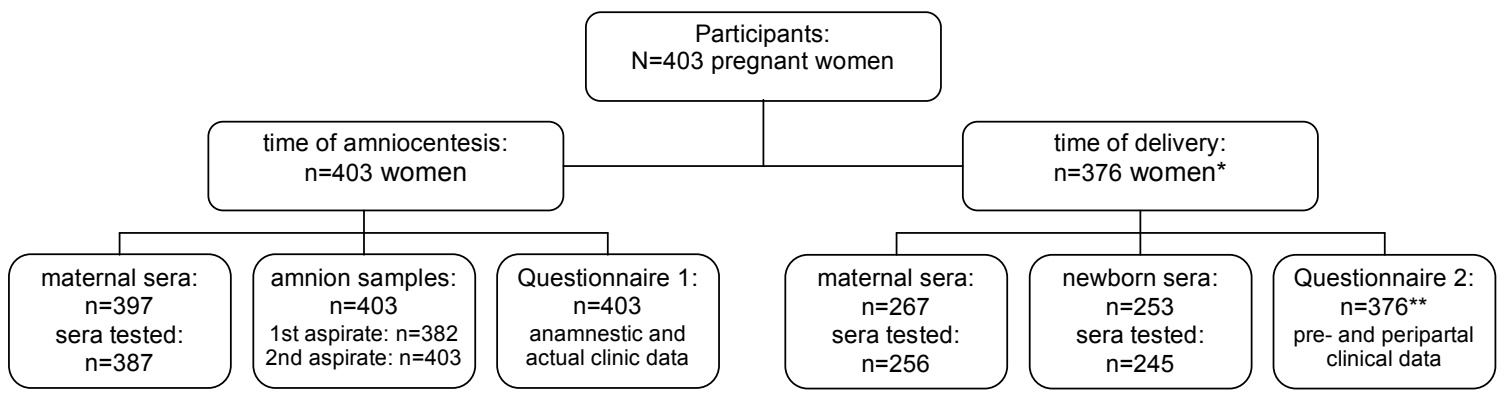

* from $n=27$ women, there was no information at the time of delivery

** among these, $n=6$ miscarriages and stillbirths

Scheme 1. 
Table 2. Distribution of Previous Pregnancies and the Respective Delivery Status in 318 Women*

\begin{tabular}{|c|c|c|c|c|c|c|}
\hline Number of Previous Pregnancies & $\begin{array}{c}\mathbf{n} \\
\text { (Women; Total n=318) }\end{array}$ & $\begin{array}{c}\mathbf{n} \\
\text { (Pregnancies) }\end{array}$ & $\begin{array}{c}\text { Live } \\
\text { Births** }\end{array}$ & $\begin{array}{c}\text { Spontaneous } \\
\text { Abortions** }\end{array}$ & $\begin{array}{c}\text { Still } \\
\text { Births** }\end{array}$ & $\begin{array}{c}\text { Missing In- } \\
\text { formation }\end{array}$ \\
\hline \hline 1 & 132 & $132(100 \%)$ & $108(81.8 \%)$ & $20(15.2 \%)$ & $1(0.8 \%)$ & $3(2.3 \%)$ \\
\hline 2 & 98 & $196(100 \%)$ & $144(73.5 \%)$ & $52(26.5 \%)$ & 0 & 0 \\
\hline 3 & 57 & $171(100 \%)$ & $104(60.8 \%)$ & $64(37.4 \%)$ & $3(1.8 \%)$ & 0 \\
\hline 4 & 21 & $84(100 \%)$ & $43(51.2 \%)$ & $39(46.2 \%)$ & $2(2.4 \%)$ & 0 \\
\hline 5 & 3 & $15(100 \%)$ & $9(60.0 \%)$ & $6(40.0 \%)$ & 0 & 0 \\
\hline$>5$ & 7 & $42(100 \%)$ & $27(64.3 \%)$ & $15(35.7 \%)$ & 0 & 0 \\
\hline
\end{tabular}

* For 85 women, the current pregnancy was the first pregnancy.

$* *$ Percentage is based on the number of the respective pregnancies.

infections of the urogenital tract $(17.1 \%)$, and previous treatment of sterility $(4.7 \%)$.

From the 403 current pregnancies, information was available for 376 deliveries (93.3\%). Of the infants, $98.4 \%$ were born alive (of those: $63 \%$ spontaneous delivery, $30 \%$ caesarean section, $6.5 \%$ others, e.g. vacuum extraction; $0.5 \%$ missings); miscarriages occurred in $1.6 \%$ of the pregnancies.

\section{Polymerase Chain Reaction on Amniotic Fluid Samples}

The two amniotic fluid aspirates were tested for HCMV DNA by nested PCR to answer the following questions: (i) Does HCMV persist in maternal cells (abdominal and uterine muscles, blood, etc.; $1^{\text {st }}$ aspirate $v s 2^{\text {nd }}$ aspirate)? (ii) To what extent does a congenital HCMV infection occur in normal pregnancies ( $2^{\text {nd }}$ aspirate; fetal cells)?

DNA extraction from the amniotic fluid samples was done using the REDExtract $\mathrm{N}-\mathrm{Amp}^{\mathrm{TM}}$ Blood PCR Kit (Sigma-Aldrich, Taufkirchen, Germany). To ascertain that only samples containing amplifiable DNA were tested for the presence of viral DNA the samples were checked for sequences of the human $\beta$-globin gene. For the $\beta$-globin PCR the following primers $\left(5^{\prime}>3^{\prime}\right)$ were used: $\beta$-globin 1 : TGA-GTC-CTT-TGG-GGA-TCT-GTC-CA and $\beta$-globin 2 : TGA-AGT-TCT-CAG-GAT-CCA-CGT-GC, giving rise to an amplified $\beta$-globin fragment of $185 \mathrm{bp}$. To amplify specific viral DNA sequences, a nested PCR was performed using the following primers $\left(5^{\prime}>3^{\prime}\right)[14]: 1^{\text {st }}$ PCR: primer pair, IEN 1 (ACA-TCT-TTC-TCG-GGG-TTC-TCG-TTGC) and IEN 2 (GTC-CTC-TGC-CAA-GAG-AAA-GATGGA-C); nested PCR: IEN 3 (TTG-AGG-GAT-TCT-TCGGCC-AAC-TCT-G) and IEN 4 (TCT-CCT-GTA-TGTGAC-CCA-TGT-GCT-T). DNA extracted from cell culture supernatants containing the HCMV strain AD 169 was used as positive control. The amplified product (170 bp in nested PCR) was identified by agarose gel electrophoresis.

\section{Serology}

Serum samples of the mothers $(\mathrm{n}=387$ at the time of amniocentesis and $\mathrm{n}=256$ at the time of delivery) and cord blood samples of the neonates $(n=245)$ were tested for HCMV-specific immunoglobulins (IgG and IgM) using the BEP-III ${ }^{\mathbb{B}}$-System (Behring Elisa Processor III, DadeBehring, Marburg, Germany).

\section{Statistical Analysis}

Power calculation: Assuming an HCMV exposure of $50 \%$ of the participants, this investigation had a power of $72 \%$ to detect a difference of $\approx 5 \%$ incidence of complications in the expected range of a complication rate of $5 \%$ (e.g., $2.5 \%-7.5 \%$ ) at the significance level of 0.05 .

$\chi^{2}$-Test and Fisher's Exact Test were performed to test for $\operatorname{IgG}$ prevalence differences, and for association between HCMV infection and clinical conditions. Significance at the $5 \%$ level was not reached in any of the tests. Therefore, only descriptive analyses are presented because numbers of comorbidity in the pregnant women were very low.

\section{RESULTS}

\section{Prevalence of HCMV DNA in Amniotic Fluids}

Amniotic fluid samples containing fetal material ("2 ${ }^{\text {nd }}$ aspirate") were tested by nested PCR in 403 cases (Table 3), with detection of HCMV DNA in 12 cases indicating a $3 \%$ prevalence of HCMV DNA in amniotic fluid/cells.

Table 3. Comparison of the Prevalences of HCMV DNA in the $1^{\text {st }}$ and $2^{\text {nd }}$ Aspirate of Amniocentesis Material $(n=403)$

\begin{tabular}{|c|c|c|c|c|c|c|c|}
\hline & & \multicolumn{6}{|c|}{$2^{\text {nd }}$ Aspirate } \\
\hline & & \multicolumn{2}{|c|}{$\begin{array}{c}\text { HCMV } \\
\text { DNA-Positive }\end{array}$} & \multicolumn{2}{|c|}{$\begin{array}{c}\text { HCMV } \\
\text { DNA- } \\
\text { Negative }\end{array}$} & \multicolumn{2}{|c|}{ Total } \\
\hline & & $\mathbf{n}$ & $\%$ & $\mathbf{n}$ & $\%$ & $\mathbf{n}$ & $\%$ \\
\hline \multirow{4}{*}{ 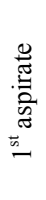 } & HCMV DNA-positive & 2 & 0.5 & 41 & 10.2 & 43 & 10.7 \\
\hline & HCMV DNA-negative & 10 & 2.5 & 329 & 81.6 & 339 & 84.1 \\
\hline & Missing & 0 & 0 & 21 & 5.2 & 21 & 5.2 \\
\hline & Total & 12 & 3.0 & 391 & 97.0 & 403 & 100 \\
\hline
\end{tabular}

As explained in the "Material and Methods" section, samples from amniotic fluids were obtained in two fractions. The "first" aspirate is assumed to contain maternal material (cells, blood, tissue) and therefore is usually discarded. The "second" aspirate contains only fetal material. The $1^{\text {st }}$ aspirate was found to be HCMV DNA-positive in 43 of the 382 
cases that could be analyzed. Thus HCMV infection of probably maternal origin was found in $11.3 \%$ of the pregnancies, and was not necessarily accompanied by infection of fetal cells. The fact that only $2 / 122^{\text {nd }}$ aspirates were also HCMV DNA-positive in the $1^{\text {st }}$ aspirate argues against "contamination" of $2^{\text {nd }}$ aspirates with maternal material.

Comparison of Detection of HCMV DNA with Serum Antibodies at the Time of Amniocentesis and Delivery (cf., Table 4)

For this issue, data from participants were analyzed if there was serum and DNA data available. Of the $11 \mathrm{HCMV}$ DNA-positive cases ( $2^{\text {nd }}$ aspirate of amniotic fluid) only $45 \%$ of the mothers' sera were anti-HCMV IgG-positive at the time of amniocentesis. Interestingly, the same percentage $(45 \%)$ of anti-HCMV seropositivity was found in the 359
HCMV DNA-negative cases (Table 4). IgM antibodies occurred in none of the 11 HCMV DNA-positive cases and in $0.8 \%(3 / 359)$ of the HCMV DNA-negative cases. Similarly, there was no association between HCMV DNA in the $1^{\text {st }}$ aspirate and HCMV antibodies at the time of amniocentesis (only about $50 \%$ of the DNA-positive cases were also IgGpositive). There was also no correlation with viral DNA $\left(1^{\text {st }}\right.$ or $2^{\text {nd }}$ aspirates) and HCMV antibodies (maternal or newborn sera) at the time of delivery (data not shown).

\section{Association of Clinical Observations and HCMV Infec- tion}

As shown in Table 5, specific pre- or peripartal complications occurred more often in cases where HCMV DNA had been detected in fetal amniocentesis material $\left(2^{\text {nd }}\right.$ aspirate). Notably, preeclampsia (18.2\% vs 3.9\%) and premature labor $(9.1 \%$ vs $4.2 \%)$ were found more frequently in women

Table 4. Prevalence of HCMV Serum Antibodies (IgG, IgM) at the Time of Amniocentesis with Regard to HCMV DNA in Amniotic Fluids ( ${ }^{\text {nd }}$ Aspirate)

\begin{tabular}{|c|c|c|c|c|c|c|c|c|c|c|c|c|c|c|c|c|}
\hline \multirow{3}{*}{$\begin{array}{c}\text { HCMV } \\
\text { DNA }\end{array}$} & \multicolumn{8}{|c|}{ Anti-HCMV IgG } & \multicolumn{8}{|c|}{ Anti-HCMV IgM } \\
\hline & \multicolumn{2}{|c|}{ Positive } & \multicolumn{2}{|c|}{ Negative } & \multicolumn{2}{|c|}{ Missing } & \multicolumn{2}{|c|}{ All } & \multicolumn{2}{|c|}{ Positive } & \multicolumn{2}{|c|}{ Negative } & \multicolumn{2}{|c|}{ Missing } & \multicolumn{2}{|c|}{ All } \\
\hline & $\mathbf{n}$ & $\%$ & $\mathbf{n}$ & $\%$ & $\mathbf{n}$ & $\%$ & $\mathbf{n}$ & $\%$ & $\mathbf{n}$ & $\%$ & $\mathbf{n}$ & $\%$ & $\mathbf{n}$ & $\%$ & $\mathbf{n}$ & $\%$ \\
\hline Positive & 5 & 45,5 & 6 & 54.5 & 0 & 0 & 11 & 100 & 0 & 0 & 11 & 100 & 0 & 0 & 11 & 100 \\
\hline Negative & 163 & 45,4 & 183 & 51.0 & 13 & 3.6 & 359 & 100 & 3 & 0.8 & 343 & 95.5 & 13 & 3.6 & 359 & 100 \\
\hline All & 168 & 45.4 & 189 & 51.1 & 13 & 3.5 & 370 & 100 & 3 & 0.8 & 354 & 95.7 & 13 & 3.5 & 370 & 100 \\
\hline
\end{tabular}

Table 5. Distribution of Clinical Conditions with Respect to Detection of HCMV DNA in Amniotic Fluid (2 ${ }^{\text {nd }}$ Aspirate)

\begin{tabular}{|c|c|c|c|c|c|}
\hline & & \multicolumn{4}{|c|}{ HCMV DNA } \\
\hline & & $\mathbf{n}$ & $\%$ & n & $\%$ \\
\hline \multirow{2}{*}{ Weight at birth (adjusted for duration of pregnancy) } & Hypotrophic (SGA*) & 2 & 18.2 & 50 & 13.9 \\
\hline & Eutrophic $\left(\mathrm{AGA}^{*}\right)$ & 9 & 81.8 & 278 & 77.4 \\
\hline \multirow{4}{*}{ Delivery with respect to duration of pregnancy } & Preterm ( $\leq 259$ days $)$ & 2 & 18.2 & 41 & 11.4 \\
\hline & At term (260-293 days) & 9 & 81.8 & 277 & 77.2 \\
\hline & Late term ( $\geq 294$ days) & 0 & 0 & 14 & 3.9 \\
\hline & missings & 0 & 0 & 27 & 7.5 \\
\hline \multirow{5}{*}{ Specific pre- and peripartal complications** } & Preeclampsia & 2 & 18.2 & 14 & 3.9 \\
\hline & Gestational diabetes & 0 & 0 & 13 & 3.6 \\
\hline & Amnion infection syndrome & 0 & 0 & 4 & 1.1 \\
\hline & Pathologic $\mathrm{CTG}^{* * *}$ & 0 & 0 & 41 & 11.4 \\
\hline & Prepartal bleeding & 0 & 0 & 12 & 3.3 \\
\hline \multirow{3}{*}{ Malformations } & Yes & 0 & 0 & 3 & 0.8 \\
\hline & No & 10 & 90.9 & 337 & 93.9 \\
\hline & missing & 1 & 9.1 & 19 & 5.3 \\
\hline
\end{tabular}

* Appropriate (A), small (S), large (L) for gestational age (GA).

** Multiple assessments possible (therefore percentages do not sum up to 100)

$* * * \mathrm{CTG}=$ Cardiotocogram. 
with HCMV-infected amnion cells. In contrast, other complications such as premature rupture of membranes and placental failure did not seem to be associated with the presence of viral DNA in amniotic fluid.

Preterm delivery (observed in $11.6 \%(n=43)$ of 370 live births) occurred more often among mothers with HCMV DNA-positive amniotic fluid ( $2^{\text {nd }}$ aspirate) than in the group of HCMV DNA-negative cases $(18.2 \%$ and $11.4 \%$, respectively; Table 5).

As also shown in Table 5, eighteen percent of children from mothers with HCMV DNA in the $2^{\text {nd }}$ aspirate were small for gestational age (SGA) compared to $13.9 \%$ immature children in the HCMV DNA-negative group.

For women with HCMV DNA in the $2^{\text {nd }}$ amniotic aspirate who had perinatal disturbances, we checked for nonviral risk factors that could influence the course of pregnancy, delivery or child development. Except for two cases, no risk factors such as previous disease or smoking or alcohol drinking at early stages of pregnancy were reported. For one growth-restricted infant, the mother had reported to smoke regularly, and in addition, she had bleeding in early pregnancy as well as vaginal infections. In the second case, of a mother with preeclampsia and the child born 20 days prior to term (but eutrophic), bleeding in early pregnancy was reported.

There was one fetal death four days after routine amniocentesis; this fetus was infected with HCMV. Pathologic examination of the fetus did not show fetal injury and gave no further information about the reasons for intrauterine fetal death. HCMV DNA was not detected in the amniotic fluid of any of the miscarriages $(n=5)$.

No association was found for latent (maternal) or fetal HCMV infection with miscarriages or fetal deaths in previous pregnancies, neither when considering the presence of viral DNA nor with regard to HCMV antibodies in the serum (data not shown).

Interestingly, in women with an assumed maternal latent infection (viral DNA detected in the $1^{\text {st }}$ aspirate), a pathological CTG was observed in $20 \%$ of women with virus DNA compared to $10 \%$ in DNA-negative mothers. Preeclampsia was found in $12 \%$ of DNA-positive cases $v s$ $3 \%$ of HCMV DNA-negative cases. In these latently infected women, a rather high association with preterm delivery was found: in 22\% of DNA-positive cases vs 11\% of HCMV DNA-negative ones. Growth restricted infants were observed in $24 \%$ of HCMV-infected cases and in $13 \%$ of those without HCMV DNA.

\section{Prevalence of Anti-HCMV Serum Antibodies}

At the time of amniocentesis, 387 (maternal) sera were available (96\% of the 403 participants). The prevalence of anti-HCMV IgG antibodies was $46.8 \%$ (Table 6). At the time of delivery, $40.6 \%$ of 256 maternal sera available were HCMV IgG antibody-positive, and anti-HCMV IgG was found in $41.6 \%$ of 245 newborn sera available (the difference in IgG prevalence of the mothers' sera at the two time points was not significant). IgM antibodies were detected at the time of amniocentesis in 3 of the 387 cases $(0.8 \%)$. At delivery, 2 of the 256 maternal sera were IgM-positive
$(0.8 \%)$. Out of the 245 newborn sera, none was found to contain anti-HCMV IgM.

\section{DISCUSSION}

Today HCMV infection is the most common congenital viral infection and may have severe effects on the fetus [15]. Yet HCMV screening in pregnancy is not routinely performed in Germany, Austria, Switzerland and other European countries because of financial reasons and the lack of either a standardized treatment regimen or a vaccine [16]. Previous studies dealing with severe clinical consequences of congenital HCMV infection are of limited relevance because of the selection of the study participants based on their HCMV serostatus [7, 17, 18]. In the present study, we investigated the prevalence of in utero infection with HCMV and evaluated its clinical relevance in a relatively large cohort of pregnant women who underwent amniocentesis for nonvirological reasons.

Table 6. Comparison of HCMV Antibody Seropositivity

\begin{tabular}{|c|c|c|c|c|c|c|}
\hline \multirow{2}{*}{ Serum* } & \multicolumn{2}{|c|}{ Sample Size } & \multicolumn{2}{c|}{ IgG-Positive } & \multicolumn{2}{c|}{ IgM-Positive } \\
\cline { 2 - 7 } & $\mathbf{n} * *$ & $\%$ & $\mathbf{n}$ & $\%$ & $\mathbf{n}$ & $\%$ \\
\hline \hline Mother, amnioc. & 387 & 100 & 181 & 46.8 & 3 & 0.8 \\
\hline Mother, delivery & 256 & 100 & 104 & 40.6 & 2 & 0.8 \\
\hline Newborn & 245 & 100 & 102 & 41.6 & 0 & 0 \\
\hline
\end{tabular}
* Mother, amnioc.: maternal sera, at the time of amniocentesis.
Mother, delivery: maternal sera, at delivery.
Newborn: newborns' sera (cord blood).
** Sera available for testing.

However, this study also has some limitations. We could collect amniocentesis material, serum samples and questionnaires from the majority of women enrolled in the study. However seven percent of the pregnancies could not be followed up until delivery; hence misclassification due to loss of follow-up cannot be totally excluded. Since most of the women who were lost were moving out of the study for nonmedical reasons (none of them had HCMV DNA-positive amniotic fluids), there should be no differential bias. Information on co-morbidities, the course of pregnancy and delivery was not self-reported but given reliably by the gynecologist or the obstetricians, respectively. Therefore, information on alcohol consumption and smoking might be biased.

In contrast to the high response rate at the time of amniocentesis, at the time of delivery, sera (from mothers and newborns) were not available for a number of participants. However, there were no hints from the questionnaires that delivery complications occurred more often in such cases than in those women for whom maternal and child's sera were provided.

Among the 403 amniotic fluid samples tested by nested PCR, 12 HCMV DNA-positive cases were detected revealing as expected low prevalence of HCMV DNA in amniotic fluid. The value established here (about 3\%), is however higher than that reported by Baschat et al. $(0.7 \%)$ in a similar population [13]. Other groups reporting a much higher prevalence (48.5\% [17], 42.1\% [18], and 17\% [7]) had examined only amniotic fluid of women who had been classi- 
fied as primarily or recurrently infected before amniocentesis. In contrast, in the present study, amniotic fluids were collected for non-virological reasons, before the $20^{\text {th }}$ week of pregnancy. Amniocentesis performed later during pregnancy (e.g. between the $20^{\text {th }}$ and $24^{\text {th }}$ week of pregnancy) seems to render detection of viral HCMV DNA more likely [7], perhaps due to virus excretion in fetal urine. Thus, our rather early prenatal diagnosis and the non-selection of women for indication of HCMV infection, may contribute to the lower prevalence of viral DNA in amniotic fluid.

HCMV DNA in amniocentesis material was rarely detected in women of this study ( $3 \%$, see above), and no severe clinical symptoms were identified in the newborns of women who had HCMV DNA-positive amniotic fluids. In particular, malformations like microcephaly, intracranial calcifications and ventriculomegaly [19] were not observed. Miscarriages occurring in the study were all from HCMV DNA-negative women. In the single case of fetal death occurring 4 days after amniocentesis, in which amnion material had been HCMV DNA-positive, there was no evidence of fetal abnormalities.

On the other hand, preterm delivery occurred more often when the amniotic fluid was tested positive for HCMV DNA ( $18 \%$ vs $11 \%$ in HCMV DNA-negative cases). This is in line with the prevalence of preterm delivery in HCMV-infected neonates reported by Boppana et al. [19]. In addition, premature labor, preeclampsia and birth of growth restricted infants occurred more often in women with HCMV DNApositive amniotic fluid, which could be a hint for an influence of congenital HCMV infection (of fetus or placenta) on intrauterine growth. However, because of the small numbers of cases these data have to be interpreted carefully.

The data indicate that in utero infection with HCMV is usually rare in pregnant women and is rarely accompanied by serious clinical findings up to the time of delivery. However, long-term pathological consequences of congenital HCMV infection could not be addressed in our study cohort because the follow-up period ended shortly after delivery. This cannot be excluded and requires further investigations.

The prevalence of HCMV DNA in amniotic fluids, which contain maternal material ( $1^{\text {st }}$ aspirate), indicates a latent infection of maternal cells. Out of the HCMV DNA-positive samples of the second aspirate (fetal cells) only two samples of the respective first aspirate were also positive for viral DNA. This argues against contamination of the second amniotic fluid aspirate during the "first" aspiration. This observation is in line with the proposal of Liesnard et al. [20] and Revello and Gerna [16] who postulated that amniocentesis itself poses no risk for transmission of the virus from the mother's abdominal wall to the fetus.

Concerning HCMV-specific IgG in maternal serum samples, we found a prevalence of $46.8 \%$ (at the time of amniocentesis) and $40.6 \%$, (at the time of delivery), respectively (this difference is not significant). In serum samples from the neonates we also tested $41.6 \%$ positive for specific IgG. These immunological data are consistent with previous reports [21-23]. Interestingly, detection of HCMV DNA in amniotic fluid samples was only paralleled in about $50 \%$ of the cases by the presence of IgG antibodies in maternal serum (at the time of amniocentesis].
$\operatorname{IgG}$ antibodies can be transferred from the mother to the fetus protecting the fetus from primary HCMV infection. In this study, $50.6 \%$ of mothers were (HCMV-) IgG-postive at one of the time points tested (amniocentesis and/or delivery). For this study population, $80.6 \%$ of newborns had serum $\mathrm{IgG}$; hence antibodies had been transferred from the mothers. The rate of transfer of IgG was higher when the mother was seropositive at the time of amniocentesis (76.6\%) compared to those cases in which the mother had HCMV IgG only at the time of delivery (4\%). The transfer rate was highest when the mother was seropositive at both time points (87\%). Possibly, stable HCMV IgG in the mother's serum is favorable for IgG transmission to the unborn child (cf., [24]).

Our results for specific IgM-antibodies confirm prevalences reported by Halwachs-Baumann et al. [4]. However, to obtain more reliable serum data concerning transmission of HCMV, in addition to evaluation of IgM status, IgG avidity tests may also have to be performed. These data should additionnally be accompanied by determination of HCMV DNA load in amniotic fluid [18].

\section{CONCLUSION}

The data presented support earlier findings and indicate that some pregnancy problems such as preeclampsia, preterm delivery, and maturity of the newborn may be associated with HCMV infection. Long-term effects of congenital HCMV infection could not be addressed in our study. However, our results should incite broader investigations (in a large population), which should address not only pathologies of the infant (congenital HCMV infection) but also a possible influence of HCMV on pregnancy complications.

\section{ACKNOWLEDGEMENTS}

We thank R. Ly and M. Ehrbar for technical support as well as J. Aldinger and B. Kohlhoff for providing samples. The assistance of I. Hettinger and S. Estel with data management and statistical analysis is gratefully acknowledged. We are very grateful to W. Eggert-Kruse for valuable discussions and to V. Bosch for critical reading of the manuscript.

We also want to thank the following hospitals for collaboration: Department of Obstetrics and Gynecology of the University Hospital Heidelberg; St. Vincentius Krankenhaus, Karlsruhe; Siloah Krankenhaus, Pforzheim; St. Trudpert Krankenhaus, Pforzheim; Städtisches Krankenhaus, Pforzheim; Kreiskrankenhaus, Freudenstadt; Enzkreiskliniken, Mühlacker.

\section{REFERENCES}

[1] Ahlfors K. Epidemiological studies of congenital cytomegalovirus infection. Scand J Infect Dis Suppl 1982; 34: 1-36.

[2] Stagno S, Whitley RJ. Herpesvirus infections of pregnancy. Part II: Herpes simplex virus and varicella-zoster virus infections. N Engl J Med 1985; 313(21): 1327-30.

[3] Ho M. Cytomegalovirus. Biology and infection. 2nd ed. New York, N.Y.: Plenum Medical Press; 1991.

[4] Halwachs-Baumann G, Genser B, Danda M, et al. Screening and diagnosis of congenital cytomegalovirus infection: a 5-y study. Scand J Infect Dis 2000; 32(2): 137-42.

[5] Demmler GJ. Infectious Diseases Society of America and Centers for Disease Control. Summary of a workshop on surveillance for congenital cytomegalovirus disease. Rev Infect Dis 1991; 13(2): 315-29. 
[6] Stagno S, Pass RF, Dworsky ME, et al. Congenital cytomegalovirus infection: The relative importance of primary and recurrent maternal infection. N Engl J Med 1982; 306(16): 945-9.

[7] Enders G, Bader U, Lindemann L, Schalasta G, Daiminger A. Prenatal diagnosis of congenital cytomegalovirus infection in 189 pregnancies with known outcome. Prenat Diagn 2001; 21(5): 36277.

[8] Halwachs-Baumann G. The congenital cytomegalovirus infection: virus-host interaction for defense and transmission. Curr Pharm Biotechnol 2006; 7(4): 303-12.

[9] Nigro G, Anceschi MM, Cosmi EV. Clinical manifestations and abnormal laboratory findings in pregnant women with primary cytomegalovirus infection. Brit J Obstet Gynaceol 2003; 110(6): 5727.

[10] Eggers M, Metzger C, Enders G. Differentiation between acute primary and recurrent human cytomegalovirus infection in pregnancy, using a microneutralization assay. J Med Virol 1998; 56(4): 351-8.

[11] Boppana SB, Fowler KB, Britt WJ, Stagno S, Pass RF. Symptomatic congenital cytomegalovirus infection in infants born to mothers with preexisting immunity to cytomegalovirus. Pediatrics 1999; 104(1 Pt 1): 55-60.

[12] Casteels A, Naessens A, Gordts F, De Catte L, Bougatef A, Foulon W. Neonatal screening for congenital cytomegalovirus infections. J Perinat Med 1999; 27(2): 116-21.

[13] Baschat AA, Towbin J, Bowles NE, Harman CR, Weiner CP. Prevalence of viral DNA in amniotic fluid of low-risk pregnancies in the second trimester. J Matern Fetal Neonatal Med 2003; 13(6): 381-4.

[14] Arai S, Mangano M, Starr SE, Spivack J. Optimization of conditions for detecting human cytomegalovirus DNA with nested PCR. In: Becker Y, Darai G, editors. PCR protocols for diagnostics of human and animal virus diseases. 1. Auflage ed. Berlin, Heidelberg, New York: Springer Verlag; 1995. p. 205-213.
[15] Nelson CT, Demmler GJ. Cytomegalovirus infection in the pregnant mother, fetus, and newborn infant. Clin Perinatol 1997; 24(1): 151-60.

[16] Revello MG, Gerna G. Diagnosis and management of human cytomegalovirus infection in the mother, fetus, and newborn infant. Clin Microbiol Rev 2002; 15(4): 680-715.

[17] Guerra B, Lazzarotto T, Quarta S, et al. Prenatal diagnosis of symptomatic congenital cytomegalovirus infection. Am J Obstet Gynecol 2000; 183(2): 476-82.

[18] Lazzarotto T, Varani S, Guerra B, Nicolosi A, Lanari M, Landini MP. Prenatal indicators of congenital cytomegalovirus infection. J Pediatr 2000; 137(1): 90-5.

[19] Boppana SB, Pass RF, Britt WJ, Stagno S, Alford CA. Symptomatic congenital cytomegalovirus infection: neonatal morbidity and mortality. Pediatr Infect Dis J 1992; 11(2): 93-9.

[20] Liesnard C, Donner C, Brancart F, Gosselin F, Delforge ML Rodesch F. Prenatal diagnosis of congenital cytomegalovirus infection: prospective study of 237 pregnancies at risk. Obstet Gynecol 2000; 95(6 Pt 1): 881-8.

[21] Boppana SB, Rivera LB, Fowler KB, Mach M, Britt WJ. Intrauterine transmission of cytomegalovirus to infants of women with preconceptional immunity. N Engl J Med 2001; 344(18): 1366-71.

[22] Genser B, Truschnig-Wilders M, Stunzner D, Landini MP, Halwachs-Baumann G. Evaluation of five commercial enzyme immunoassays for the detection of human cytomegalovirus-specific IgM antibodies in the absence of a commercially available gold standard. Clin Chem Lab Med 2001; 39(1): 62-70.

[23] Gouarin S, Palmer P, Cointe D, et al. Congenital HCMV infection: a collaborative and comparative study of virus detection in amniotic fluid by culture and by PCR. J Clin Virol 2001; 21(1): 47-55.

[24] Fowler KB, Stagno S, Pass RF. Maternal immunity and prevention of congenital cytomegalovirus infection. JAMA 2003; 289: 10081011 .

(C) Wenig et al.; Licensee Bentham Open.

This is an open access article distributed under the terms of the Creative Commons Attribution License (http://creativecommons.org/license/by/2.5/), which permits unrestrictive use, distribution, and reproduction in any medium, provided the original work is properly cited. 